\title{
Characteristics of deep drainage and soil water in the mobile sandy lands of Inner Mongolia, northern China
}

\author{
XinPing LIU ${ }^{1,2 *}$, YuHui HE ${ }^{1,2}$, XueYong ZHAO ${ }^{1,2}$, TongHui ZHANG ${ }^{1,2}$, LaMei ZHANG ${ }^{1,2}$, YunHua MA ${ }^{1,2}$, \\ ShuXia YAO ${ }^{1,2}$, ShaoKun WANG ${ }^{1,2}$, ShuiLian WEI ${ }^{1,2}$ \\ ${ }^{1}$ Naiman Desertification Research Station, Cold and Arid Regions Environmental and Engineering Research Institute, Chinese \\ Academy of Sciences, Lanzhou 730000, China; \\ ${ }^{2}$ Laboratory of Stress Ecophysiology and Biotechnology, Cold and Arid Regions Environmental and Engineering Research \\ Institute, Chinese Academy of Sciences, Lanzhou 730000, China
}

\begin{abstract}
Quantification of deep drainage and the response of soil water content to rainfall patterns are critical for an effective management strategy of soil water conservation and groundwater utilization. However, there has been little information on how rainfall characteristics influence soil water dynamics and deep drainage in mobile sandy lands. We used an underground chamber to examine the responses of deep drainage and soil water content in mobile sandy lands to rainfall characteristics in Inner Mongolia during the growing seasons of 2010, 2011 and 2012. Results showed that rainfall in this area was dominated by small events $(\leq 5 \mathrm{~mm})$, which increased soil water content in the surface soil layers $(0-40 \mathrm{~cm})$, but did not increase soil water content in the deeper soil layers (greater than $40 \mathrm{~cm}$ ). Soil water content at the $0-100 \mathrm{~cm}$ depth increased significantly when the total amount of rain was $>20 \mathrm{~mm}$. Rainfall amount, intensity and the duration of dry intervals were significantly related to the soil water content in different soil layers. Deep drainage was significantly correlated with rainfall amount and intensity, but not with the duration of dry intervals. The coefficients of deep drainage in the mobile sandy lands ranged from $61.30 \%$ to $67.94 \%$ during the growing seasons. Our results suggested that rainfall infiltration in the mobile sandy lands had considerable potential to increase soil water storage while recharging the groundwater in this region.
\end{abstract}

Keywords: mobile sandy lands; rainfall characteristics; deep drainage; soil water content

Citation: XinPing LIU, YuHui HE, XueYong ZHAO, TongHui ZHANG, LaMei ZHANG, YunHua MA, ShuXia YAO, ShaoKun WANG, ShuiLian WEI. 2015. Characteristics of drainage and soil water in the mobile sandy lands of Inner Mongolia, northern China. Journal of Arid Land, 7(2): 238-250. doi: 10.1007/s40333-014-0095-4

Increasing water demands of agricultural, household and ecological environment in semi-arid and arid regions result in a critical status of groundwater recharge (Scanlon et al., 2006). The amount of rainwater infiltrating the soil surface directly affects the quantity of the recharge of both soil water and groundwater, while groundwater is typically regarded as an alternative to surface water in semi-arid areas, northern China (Jang et al., 2010, 2013; Ma et al., 2013). Soil water plays a key role in controlling the partitioning of precipitation between evapotranspiration and deep infiltration (Daly and Porporato, 2005). The change in soil water content is at the core of the hydrological cycle in earth system studies (Zhang and Luo, 1984; Song et al., 2007; Legates et al., 2011), and constitutes the greatest limitation affecting plant growth (Morenode Las Heras et al., 2011). Sustainable management of water resources to meet human and ecosystem needs will require accurate estimation of groundwater recharge and soil water dynamics, as the surface water sources are generally scarce and highly unstable in arid and semi-arid regions (Scanlon et al., 2006;

"Corresponding author: XinPing LIU (E-mail: liuxinping@lzb.ac.cn) Received 2014-04-24; revised 2014-07-17; accepted 2014-09-01

(C) Xinjiang Institute of Ecology and Geography, Chinese Academy of Sciences, Science Press and Springer-Verlag Berlin Heidelberg 2015 
Gates et al., 2008; Mehmet, 2008).

Rainfall characteristics, infiltration process, surface run-off and evapotranspiration have been identified as key factors in determining the temporal and spatial heterogeneity of soil water content and infiltration recharge (Reynolds et al., 2004; Salve et al., 2011; Wang et al., 2013). Small rainfall events usually affect only the shallow soil layers and easily lost through direct evaporation, whereas large rainfall events increase soil water content and permit moisture penetration deeper into the soil profile (Schwinning and Sala, 2004; Heisler-White et al., 2008; He et al., 2012). Soil water content is not replenished when rainfall is less than $5 \mathrm{~mm}$, while rainfall $>20 \mathrm{~mm}$ can significantly increase soil water content in the depth from 0 to 100 $\mathrm{cm}$ in mobile dunes (Yao et al., 2013). Generally, groundwater recharge can be quantified using information from hydrogeologic and geologic investigations, hydrometeorologic data, observed discharge, and groundwater levels (Carpenter et al., 2001; Rushton et al., 2006; Sharda et al., 2006; Lucinda et al., 2008; Liu et al., 2010). However, accurate estimation of groundwater recharge for a given location is difficult because the processes are complex and depend on numerous local factors, including precipitation characteristics, evapotranspiration rate, runoff, soil structure, vegetation and land use (Foley and Silburn, 2002; Scanlon et al., 2006; Lucinda et al., 2008; Yeh et al., 2009; Huang et al., 2013; Jang et al., 2013). Furthermore, groundwater recharge has significant differences in the different regions (Delin et al., 2007), and different methods are needed to limit estimation uncertainties (Liu et al., 2011). Therefore, quantification of infiltration recharge and the response of soil water content to rainfall patterns are critical for the development of effective management strategies for the conservation of soil water and groundwater utilization.

This study was performed in the Horqin Sandy Land, which is located in the semi-arid area of eastern Inner Mongolia, China $\left(42^{\circ} 41^{\prime}-45^{\circ} 15^{\prime} \mathrm{N}\right.$, $118^{\circ} 35^{\prime}-123^{\circ} 30^{\prime} \mathrm{E}$ ), and is one of the most seriously and ecologically fragile desertification regions in China's agro-pastoral ecotone. Over recent decades, most sandy grasslands have evolved into mobile, semi-mobile and semi-fixed sandy lands due to the long-term influence of overgrazing, land reclamation, vegetation degradation and persistent drought (Zhu and Chen, 1994; Zuo et al., 2008). Moreover, excessive extraction of groundwater and continuous drought has led to decreases in groundwater levels and vegetation degradation in the Horqin Sandy Land (Chenini et al., 2010; Li et al., 2013). The effect of decrease in groundwater level on vegetation degradation, soil water dynamics and their relationships with rainfall patterns has become the focus of research on land-surface processes in this region (Liu et al., 2006; Yao et al., 2013). A previous study revealed that mobile sandy lands played an important landscape-level role in the redistribution of rainwater (Berndtsson and Nodomi, 1996). In the Horqin Sandy Land, soil water content is determined by rainfall amount and evapotranspiration rate rather than groundwater because the groundwater table is deeper than $11.0 \mathrm{~m}$ at the mobile sandy lands (Zhao et al., 2007a; Yao et al., 2013). Aeolian sandy soil presents a strong infiltration and low water-holding capacity (Alamusa et al., 2005; Yao et al., 2013), which infer that mobile dunes have important eco-hydrological functions and allow recharge groundwater after rainfall events with high intensity or amount. However, no sufficient evidences could support the inference, and limited data was available on the response of infiltration recharge and soil water content to rainfall patterns during the growing season in mobile sandy lands.

The objectives of the present study were to: (1) analyze the response of soil water content to rainfall characteristics using hourly data of soil water content during the growing seasons of 2010, 2011 and 2012; (2) quantify the extent of deep drainage and examine the relationship between deep drainage and rainfall characteristics (including rainfall amount and intensity, and the duration of dry intervals) in mobile sandy lands during the growing seasons from 2010 to 2012 .

\section{Materials and methods}

\subsection{Study sites}

The study was conducted at the Naiman Desertification Research Station, Chinese Academy of Sciences, Inner Mongolia, China. The station is located in the southern part of the Horqin Sandy Land, near Daqintala in Naiman county $\left(42^{\circ} 58^{\prime} \mathrm{N}, 120^{\circ} 43^{\prime} \mathrm{E}\right.$; $345 \mathrm{~m}$ asl; 
Fig. 1). The landscape in this area is characterized by gently undulating mobile, semi-mobile and fixed dunes (Zhang et al., 2004). The groundwater table in the mobile sandy lands was $7.5 \mathrm{~m}$ in 2005 . However, this depth increased to 9.7-12.4 $\mathrm{m}$ with an average of $11.1 \mathrm{~m}$ from 2005 to 2013 based on unpublished data obtained at the Naiman station. Climate is temperate, semi-arid continental and monsoonal, receiving 351.7 $\mathrm{mm}$ of precipitation annually, with $86.6 \%$ falling in the growing season from May to September. There is little rain or snow with small precipitation amount from September to May (Liu et al., 2011). Mean annual evaporation is about $1,935 \mathrm{~mm}$, and annual mean temperature is about $5.8-6.4^{\circ} \mathrm{C}$. The lowest and highest monthly mean temperatures are $-13.1^{\circ} \mathrm{C}(-16.6$ to $\left.-9.7^{\circ} \mathrm{C}\right)$ in January and $23.7^{\circ} \mathrm{C}\left(21.6-25.8^{\circ} \mathrm{C}\right)$ in July, respectively. The depth of the sand deposits is 20-120 m (Su et al., 2005). According to the Food and Agriculture Organisation soil classification system (IUSS, 2006), the main soil type is a Cambic Arenosol of sandy origin. Soils are light yellow, with a loose structure, and are particularly susceptible to wind erosion (Zhao et al., 2007a). Seasonal frozen soil generally occurs from October to April next year and the depth of frozen soil is between 0.9 to $1.4 \mathrm{~m}$. Soil particle sizes of mobile sandy lands are $0.10-2.00 \mathrm{~mm}$ $(>97 \%)$ and $0.05-0.10 \mathrm{~mm}$. At the depth of $0-160 \mathrm{~cm}$, average water saturation is $34.28 \%$, mean field water capacity is $17.96 \%$ and mean bulk density is 1.57 $\mathrm{g} / \mathrm{cm}^{3}$ (Table 1).

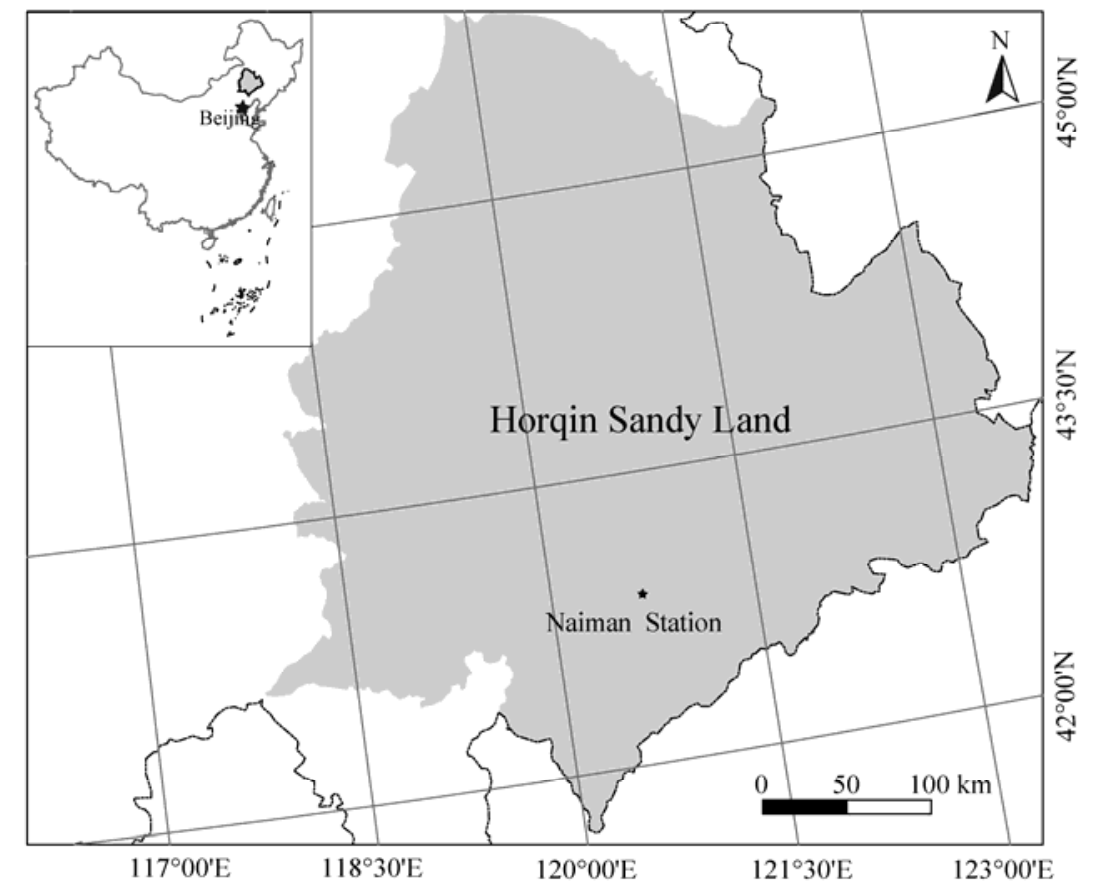

Fig. 1 Location of study site (Horqin Sandy Land in Inner Mongolia, China)

Table 1 Soil physical properties at the different soil depths in mobile sandy lands

\begin{tabular}{|c|c|c|c|c|c|c|c|c|}
\hline \multirow{2}{*}{ Soil physical property } & \multicolumn{8}{|c|}{ Soil depth $(\mathrm{cm})$} \\
\hline & $0-20$ & $20-40$ & $40-60$ & $60-80$ & $80-100$ & $100-120$ & $120-140$ & $140-160$ \\
\hline Saturation water capacity (\%) & 35.65 & 35.51 & 34.28 & 33.19 & 34.95 & 33.73 & 33.58 & 34.00 \\
\hline Field water capacity (\%) & 20.28 & 18.21 & 18.18 & 18.58 & 17.38 & 16.61 & 17.52 & 17.16 \\
\hline Bulk density $\left(\mathrm{g} / \mathrm{cm}^{3}\right)$ & 1.58 & 1.58 & 1.58 & 1.57 & 1.56 & 1.56 & 1.56 & 1.56 \\
\hline Coarse sand $(0.25-2.00 \mathrm{~mm}, \%)$ & 26.55 & 30.33 & 35.51 & 47.81 & 48.16 & 42.30 & 48.11 & 42.35 \\
\hline Fine sand $(0.25-0.10 \mathrm{~mm}, \%)$ & 70.94 & 67.48 & 63.02 & 51.39 & 51.14 & 56.47 & 51.04 & 56.16 \\
\hline Very fine sand $(0.05-0.10 \mathrm{~mm}, \%)$ & 0.97 & 1.23 & 1.17 & 0.43 & 0.25 & 0.86 & 0.53 & 0.94 \\
\hline Silt+clay $(<0.05 \mathrm{~mm}, \%)$ & 1.57 & 0.96 & 0.37 & 0.42 & 0.42 & 0.45 & 0.34 & 0.54 \\
\hline
\end{tabular}




\subsection{Experimental design}

An underground chamber was constructed in the summer of 2009 as part of a large project to study soil water dynamics and deep drainage of different vegetation types. The underground chamber consisted of 23 concrete basins, each with dimensions of 200 $\mathrm{cm} \times 200 \mathrm{~cm} \times 230 \mathrm{~cm}$; the bottom of each basin was shaped as a $30-\mathrm{cm}$ deep cone (Fig. 2). For this study, three of the basins (other basins were used to carry out different experiments) were filled with sandy soils taken from the nearby mobile sandy land (about 200 $\mathrm{m}$ ) in the summer of 2009. Soil profiles in the basins were representative of those in the mobile sandy lands; soils from different depths were put back layer by layer in $20-\mathrm{cm}$ intervals. A special filtering layer underlain by gravel was placed at the bottom of each basin to prevent sandy soil from flowing out during drainage. The filtering layer was composed of three $10-\mathrm{cm}$ layers with different-sized particles of gravel. The hydraulic conductivity of the filtering layer was higher than that of the overlying sandy soil.

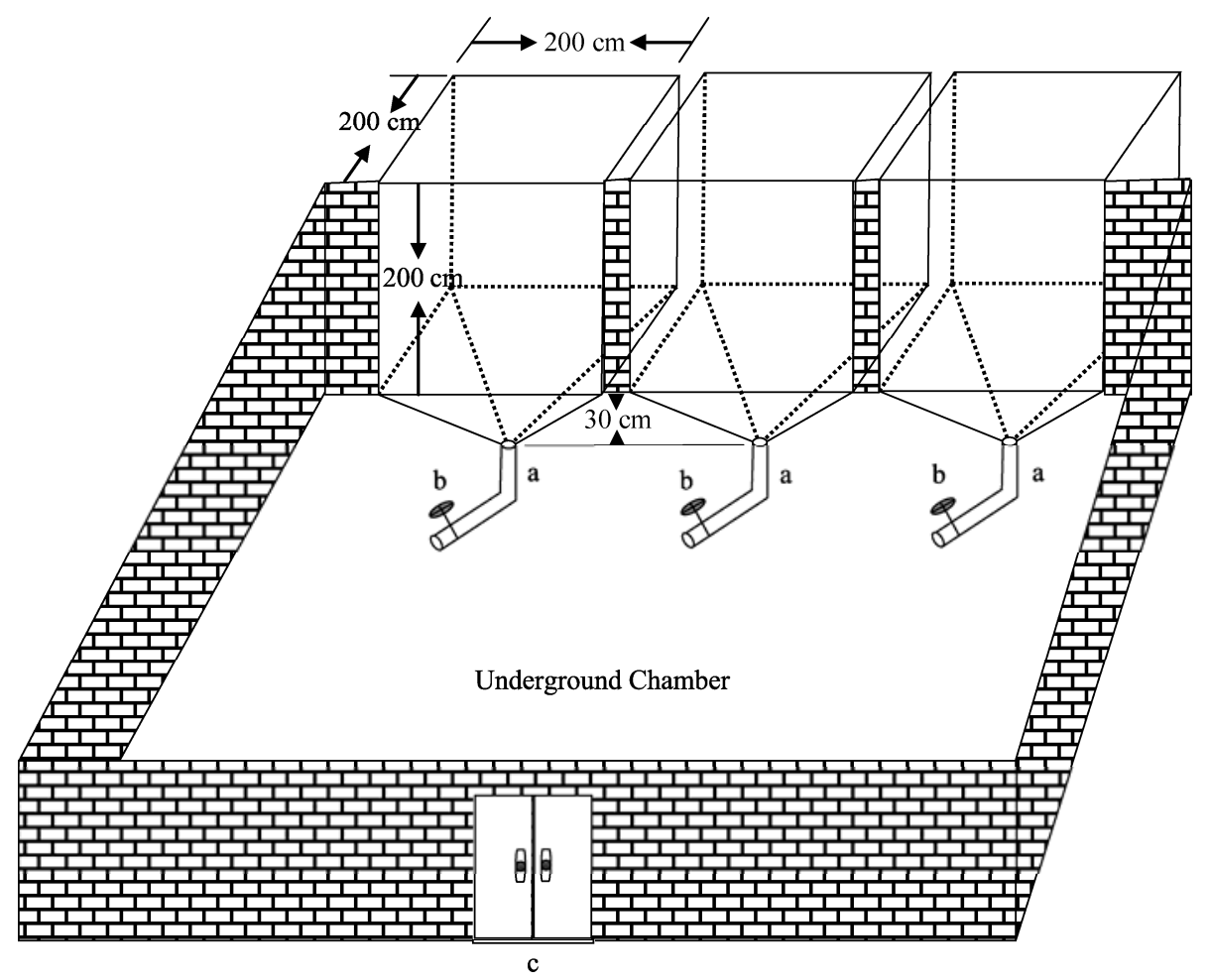

Fig. 2 Diagram of the underground chamber. (a) drainage tube; (b) water valve; (c) entrance of the underground chamber

Deep drainage is soil water which can infiltrate through the profile (below $200 \mathrm{~cm}$ ) when the soil water content reaches field capacity. Deep drainage during the growing season was collected in underground chamber using drainage tubes with valves connected to the bottom of each basin. The experiments were conducted from 4 June 2010 to 18 September 2010, 4 May 2011 to 10 September 2011 and 6 May 2012 to 10 September 2012.

\subsection{Measurements and sampling}

In each basin, three soil samples were taken at depth of $20,40,60,80,100,120,140$ and $160 \mathrm{~cm}$ using a cylindrical metal core with a volume of $100 \mathrm{~cm}^{3}$. Soil bulk density was measured by the volume-mass relationship; saturation water capacity and field capacity were determined by intact soil cores (ISSCAS, 1978). Briefly, soil cores, covered at one end with a fine mesh and left the other end open, were saturated with water for $12 \mathrm{~h}$. The resulting soil water content represented gravimetric saturation water capacity. Excess water was then drained by placing samples on the surface of a sand bed for $12 \mathrm{~h}$ for the determination of field capacity (ISSCAS, 1978). Soil particle size distribution was determined by the wet sieving method (Su and Zhao, 2003). Bulk density, distribution of particle size fractions, saturation water capacity and 
field capacity were the average of three replicates for each basin.

Volumetric soil water content was automatically recorded hourly using MiniTrase Soil Moisture Monitoring System (6050X3K1, ICT, USA) during the experiment period. This instrument provides relatively accurate and rapid method to monitor soil water content (Timlin and Pachepsky, 2002; Wang et al., 2008). Its reliability has been proved in tropical and arid environments around the world (Dunkerley and Booth, 1999; Wang et al., 2007; Yao et al., 2013). The instrument is capable of measuring volumetric moisture content between 0 and $100 \%$, with an accuracy of $\leq \pm 2.0 \%$ according to the calibration in the field using the drying oven method. In each basin, we installed 8 buried waveguides $(6005 \mathrm{~L} 2)$ at depths of $0-20,20-40$, $40-60,60-80,80-100,100-120,120-140$ and $140-160$ $\mathrm{cm}$. Soil water content of each soil layer was the average of three basins. The corresponding hourly rainfall data for the study period were obtained from an automated meteorological station less than $60 \mathrm{~m}$ away from the study site. Deep drainage was collected in the underground chamber and measured daily except for power cut. The coefficient of deep drainage was defined as the ratio of the amount of deep drainage to the amount of rainfall.

\subsection{Data analysis}

Primary statistical analysis was performed using the software of Statistical Program for Social Sciences (SPSS) (version 13.0; SPSS Inc., Chicago, IL, USA), with the level of significance for all statistical tests set at $P<0.05$. We analyzed the differences in the coefficients of deep drainage and rainfall amounts for the 3 one-way analysis of variance (ANOVA) procedures. Pearson's correlation coefficient $(r)$ was used to test the significance of the relationships among rainfall amount, rainfall intensity, duration of dry intervals, and deep drainage and soil water at different depths.

\section{Results}

\subsection{Rainfall characteristics}

The total annual rainfall was $318.3,253.6$ and $477.4 \mathrm{~mm}$ in 2010, 2011 and 2012, respectively. About 48.8\%, $91.2 \%$ and $50.2 \%$ of the total rainfall fell in the study period for each year (Fig. 3). Seventy-five rainfall events fell in the observation period (Table 2). No ponding and runoff were detected on the soil surface even under the intensive rainfall events or events with long rainfall duration. The heaviest rainfall occurred on 15 June 2012 with a rainfall amount of $56.3 \mathrm{~mm}$ (Fig. 3), a maximum 30-minute intensity of 12.47 $\mathrm{mm} / \mathrm{h}$ and an average intensity of $2.34 \mathrm{~mm} / \mathrm{h}$. The lightest rainfall occurred on 31 May 2011, with a total amount of $0.3 \mathrm{~mm}$ (Fig. 3). The minimum rainfall intensity was $0.1 \mathrm{~mm} / \mathrm{h}$ (rainfall amount $0.3 \mathrm{~mm}$ ), and the maximum was $11.8 \mathrm{~mm} / \mathrm{h}$ (rainfall amount $47.1 \mathrm{~mm}$ ). These results indicated that some rain events involved not only the high rainfall amount but also the high rainfall intensity. Between 2010 and 2012, there were 16 rainfall events of $\leq 5 \mathrm{~mm}$ during the measurement period of 2010, 15 in 2011 and 12 in 2012, which accounted for $69.6 \%, 53.6 \%$ and $50.0 \%$ of total rainfall events in those years, respectively. We also observed 9 rainfall events of $>20 \mathrm{~mm}$, total rainfall amounts $>20 \mathrm{~mm}$ were $69.4,116.7$ and $129.0 \mathrm{~mm}$ in 2010, 2011 and 2012, respectively, which accounted

Table 2 Rainfall event sizes during the growing season

\begin{tabular}{|c|c|c|c|c|c|c|}
\hline \multirow{2}{*}{ Event size (mm) } & \multicolumn{2}{|c|}{2010} & \multicolumn{2}{|c|}{2011} & \multicolumn{2}{|c|}{2012} \\
\hline & Frequency & Total amount (mm) & Frequency & Total amount (mm) & Frequency & Total amount (mm) \\
\hline$\leq 2$ & 4 & 5.7 & 9 & 10.7 & 9 & 11.1 \\
\hline $2-5$ & 12 & 39.9 & 6 & 21.0 & 3 & 10.5 \\
\hline $5-10$ & 4 & 30.1 & 6 & 41.7 & 5 & 35.4 \\
\hline $10-15$ & 1 & 10.2 & 2 & 24.4 & 3 & 38.2 \\
\hline $15-20$ & 0 & 0.0 & 1 & 16.9 & 1 & 15.5 \\
\hline $20-30$ & 0 & 0.0 & 3 & 69.6 & 1 & 25.3 \\
\hline $30-40$ & 2 & 69.4 & 0 & 0.0 & 0 & 0.0 \\
\hline$\geq 40$ & 0 & 0.0 & 1 & 47.1 & 2 & 103.7 \\
\hline Total & 23 & 155.3 & 28 & 231.4 & 24 & 239.6 \\
\hline
\end{tabular}



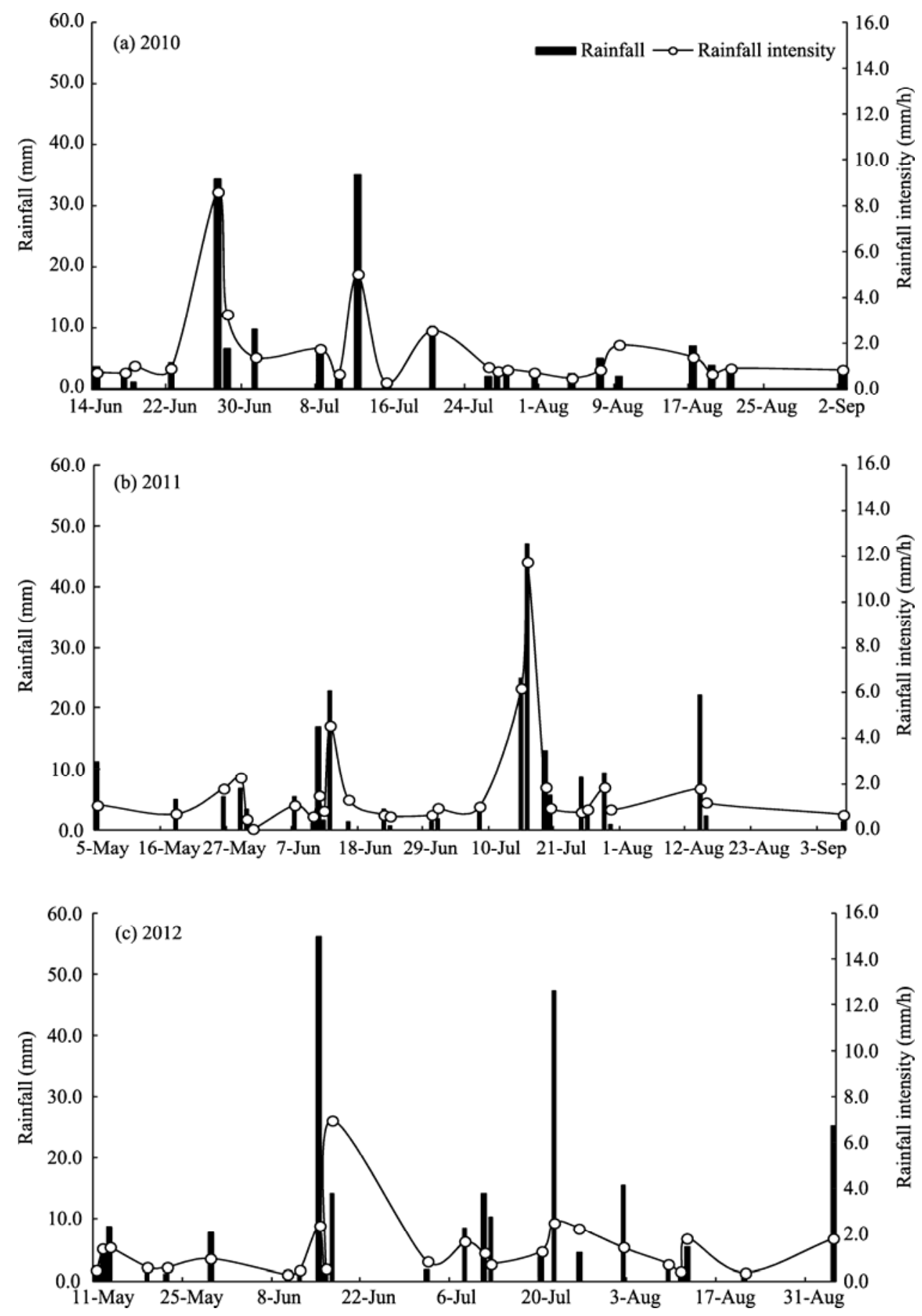

Fig. 3 Rainfall characteristics during the study period

for $44.7 \%, 50.4 \%$ and $53.8 \%$ of the precipitation each year (Table 2). During the study period, the maximum duration of the dry interval was 23 days and the minimum was 1 day.

\subsection{Soil water content}

As can be expected, with the increase in rainfall amount, soil water content also increased, particularly after heavy rain and in the upper soil layers $(0-40 \mathrm{~cm})$ (Fig. 4), 

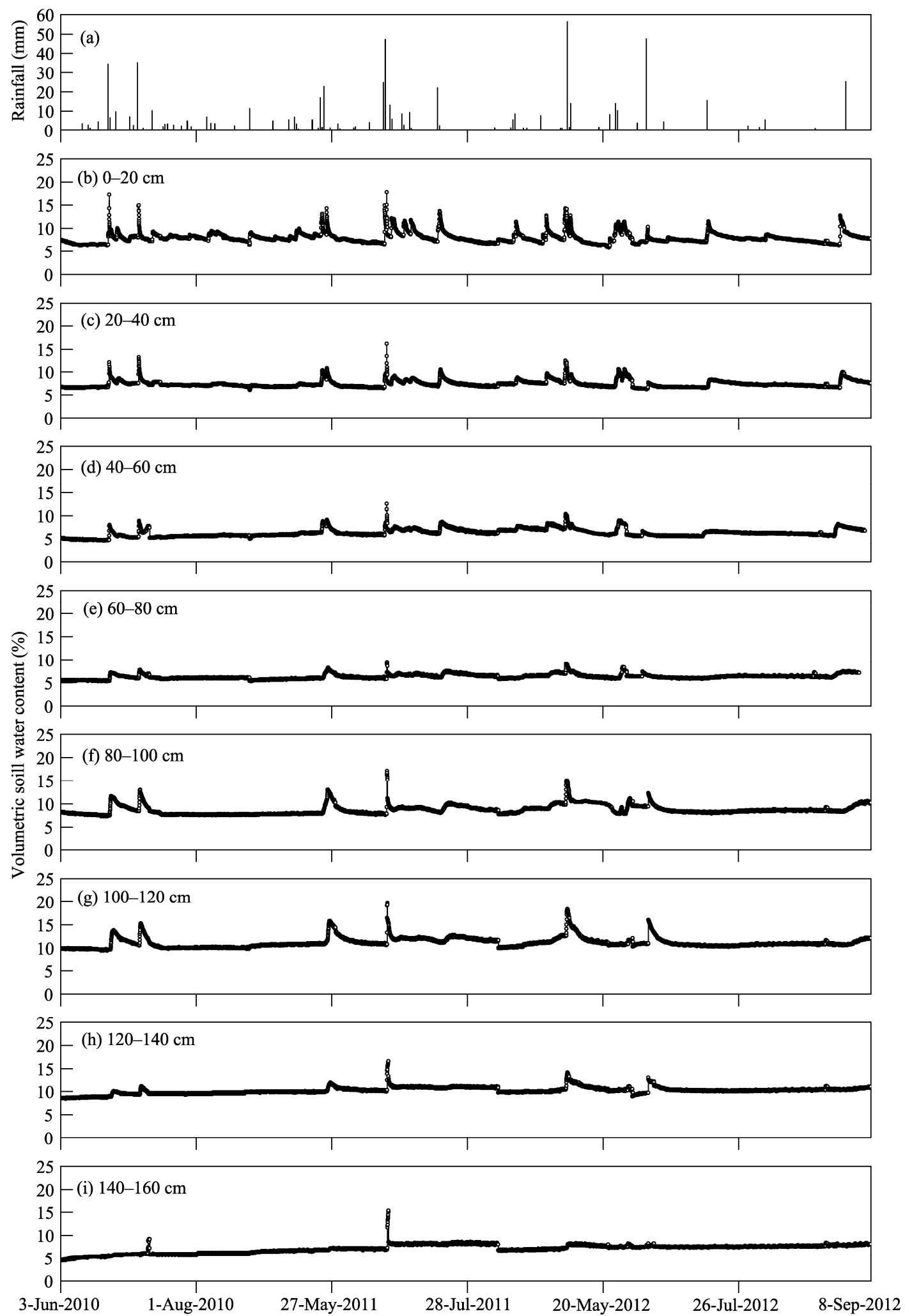

Fig. 4 Rainfall events (a) and the changes of soil water contents $(b-i)$ in mobile sandy lands during the growing seasons, 2010-2012

and these values were varied with the initial soil water content and the duration of the dry interval. The peak soil water content was related to the rainfall amount, but it gradually decreased thereafter due to evaporation and deep drainage. Soil water content at $0-100 \mathrm{~cm}$ depth increased significantly when the amount of 
rainfall was $>20 \mathrm{~mm}$ or when several consecutive rainfall events were separated by short dry intervals and delivered total rain amount $>20 \mathrm{~mm}$. Soil water content at depth of 140-160 cm only increased when rain amount of a single rain event or several large consecutive events with short dry intervals were $>40 \mathrm{~mm}$ (Fig. 4). In addition, soil water contents at depth of $0-100 \mathrm{~cm}$ were significantly correlated to rainfall amounts ( $r$ ranged from 0.239 to $0.438, P<0.05$ ).
However, soil water contents at depth of $100-160 \mathrm{~cm}$ were weakly correlated to rainfall amounts ( $r$ ranged from 0.110 to $0.201, P>0.05$ ) (Table 3). Soil water contents at depths of $0-20 \mathrm{~cm}$ and $20-40 \mathrm{~cm}$ were significantly correlated with rainfall intensity $(r=0.284$ and $r=0.244$, respectively, $P<0.05$ ). We also found a significant negative correlation between the duration of the dry interval and the soil water content at the depth of $0-20 \mathrm{~cm}(r=0.293, P<0.05)$ (Table 3$)$.

Table 3 Pearson's correlation coefficients between soil water content and rainfall characteristic

\begin{tabular}{ccccccccc}
\hline \multirow{2}{*}{ Rainfall characteristic } & \multicolumn{5}{c}{ Soil water content } \\
\cline { 2 - 7 } & $0-20 \mathrm{~cm}$ & $20-40 \mathrm{~cm}$ & $40-60 \mathrm{~cm}$ & $60-80 \mathrm{~cm}$ & $80-100 \mathrm{~cm}$ & $100-120 \mathrm{~cm}$ & $120-140 \mathrm{~cm}$ & $140-160 \mathrm{~cm}$ \\
\hline Rainfall & $0.438^{* *}$ & $0.324^{* *}$ & $0.304^{* *}$ & $0.237^{*}$ & $0.239^{*}$ & 0.201 & 0.185 \\
Rainfall intensity & $0.284^{*}$ & $0.244^{*}$ & 0.151 & -0.043 & -0.015 & 0.025 & 0.011 & -0.110 \\
Dry interval & $-0.293^{*}$ & -0.148 & -0.080 & -0.032 & -0.013 & -0.105 & -0.026 & 0.129 \\
\hline
\end{tabular}

Note: ${ }^{*}$ indicates that the correlation is significant at $P<0.05 ;{ }^{* *}$ indicates that the correlation is significant at $P<0.01$.

\subsection{Deep drainage}

No deep drainage was found from October to April next year in 2010, 2011 and 2012 due to sparse precipitation events, small precipitation amount and seasonal frozen soil. However, the amount of deep drainage was relatively stable for small rainfall events $(<20 \mathrm{~mm})$ during the study period (Fig. 5). Rainfall events $>30 \mathrm{~mm}$ resulted in a significant increase in deep drainage, especially when rainfall reached $47.1,56.3$ and $47.4 \mathrm{~mm}$. We found that deep drainage during individual rainfall event was significantly correlated with rainfall amount $(r=0.907$, $P<0.001)$ and intensity $(r=0.659, P<0.001)$, but not with the duration of the dry interval $(P>0.05)$. The coefficients of deep drainage were $61.30 \%, 67.94 \%$ and $64.80 \%$ in 2010, 2011 and 2012, respectively. Rainfall amounts differed significantly over the three-year study period $(P>0.05)$, but not the coefficients of deep drainages (Fig. 6).

\section{Discussion}

The response of soil water content at different depths to rainfall events is closely associated with the amount and intensity of rainfall (Miller and Poole, 1983; Heisler-White et al., 2008; Yaseef et al., 2010; Salve et al., 2011), and the duration of the dry interval (He et

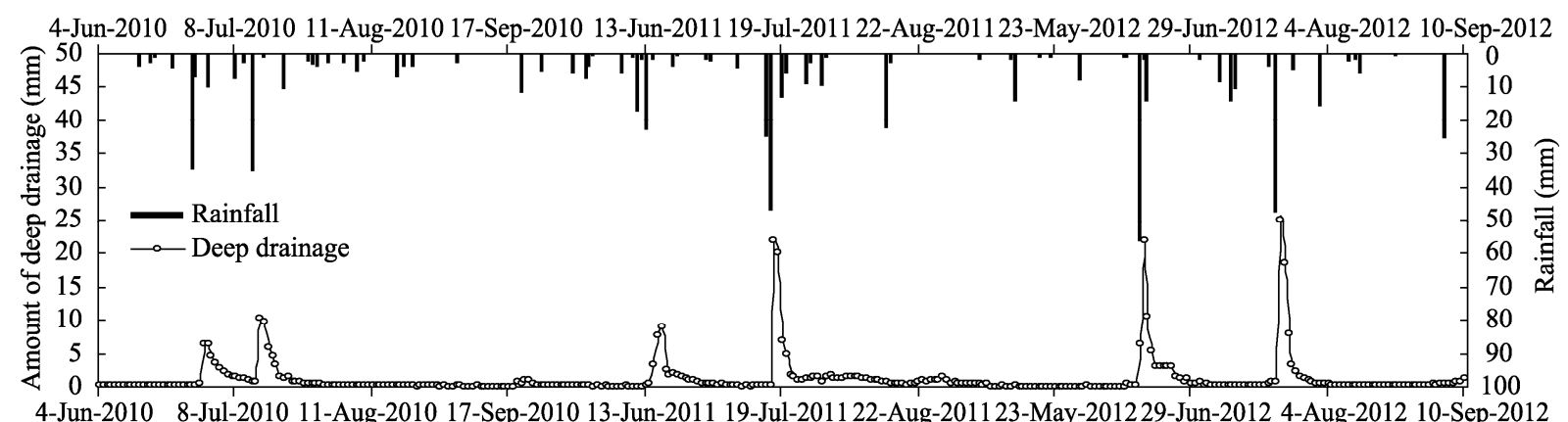

Fig. 5 Changes of deep drainage and rainfall events during the growing seasons from 2010 to 2012 


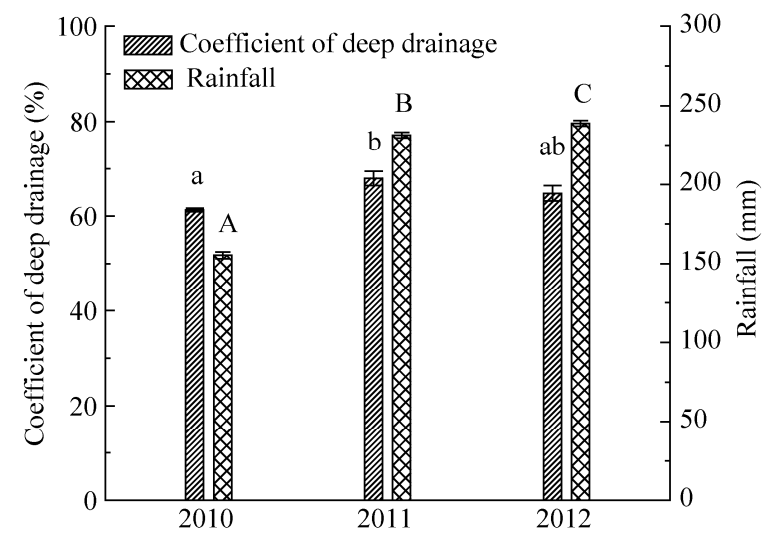

Fig. 6 Coefficients of deep drainage and rainfall amount during the growing season from 2010 to 2012. Vertical bars show S.D. Different lower case letters and capital letters indicate significant differences at $P<0.05$ level.

al., 2012). Small rainfall events may only be able to wet the uppermost soil layers when a large fraction of the soil moisture is lost by direct evaporation (Beatley, 1974; Wythers et al., 1999). Soil water is therefore mainly replenished by large rain events (Schwinning and Sala, 2004; Pan and Wang, 2009; Wang et al., 2011). In the present study, we found that small rain events increased soil water content in the surface layers $(0-40 \mathrm{~cm})$, but did not increase soil water content in the deeper soil layers (below $40 \mathrm{~cm}$ ) (Fig. 4). Our results are agree with the study conducted in the same region by Yao et al. (2013), which found that rainfall $<5 \mathrm{~mm}$ did not replenish soil water content and rainfall between 5 and $20 \mathrm{~mm}$ provided some replenishment to soil water content from 0 to $40 \mathrm{~cm}$. However, the research literatures on the precipitation infiltration were inconsistent. Tu et al. (2009) found that the active zone involving the infiltration and evaporation process was within the first $70 \mathrm{~cm}$ below the ground surface in the Loess Land. Wang et al. (2008) reported that the rainfall of $6.4 \mathrm{~mm}$ with intensity of $0.7 \mathrm{~mm} / \mathrm{h}$ was effective for soil water replenishment in the bare sand dunes of the Tengger Desert. This difference may be primarily attributed to the high infiltration capacity in the Loess Land and high content of coarse sand in the Tengger Desert. In this study, infiltration depth after small rainfall was less than $20 \mathrm{~cm}$, and strong winds in our study area tended to increase evaporation of the surface soil, leading to the deple- tion of soil water in shallow soil compared to the deeper layers (Yao et al., 2013). Furthermore, our results showed that soil water content at the depth of $0-100 \mathrm{~cm}$ increased significantly when rainfall amounts is $>20 \mathrm{~mm}$ (Fig. 4). This suggests that at least $20 \mathrm{~mm}$ of rainfall would be required for rainwater to reach a depth of $100 \mathrm{~cm}$ at mobile sandy lands. These results also confirmed the viewpoints of Finch (1998) and Yao et al. (2013) that soil water in sandy land depended strongly on the temporal and spatial variation of precipitation. Large rain events $(>20 \mathrm{~mm})$ played an important role in increasing soil water content at deep layers and in forming deep drainage in mobile sandy land.

Soil water content was significantly and positively correlated with the amount of rain at the depth of $0-100 \mathrm{~cm}$ but not at the depth of $100-160 \mathrm{~cm}$ in mobile sandy lands. Soil water contents at the depth of 0-20 cm and 20-40 cm were also significantly correlated with rainfall intensity (Table 3 ). These results indicated that a large proportion of rain water immediately evaporated due to low intensity and limited infiltration depth, and a rain event with high intensity would increase the depth of infiltration and decrease evaporation of the surface soil water accordingly. Meanwhile, soil water content in the topsoil $(0-20 \mathrm{~cm}$ depth) is significantly influenced by evaporation, namely the longer the dry interval, the more the soil water loss. These results are consistent with those from the study by Naama et al. (2012) in Southern Israel. In deep soil layers, despite the lack of a significant correlation, the duration of the dry interval could enhance or weaken the response of soil water to a rain event (Yamanaka and Yonetani, 1999).

Deep drainage in sandy areas depends on the rainfall intensity to a great extent, while non-vegetated sandy areas experiencing short, high-intensity rainfall events are more likely to display a larger fraction of rainfall as recharge (Wang et al., 2004). As shown in our study, large rain events $(>30 \mathrm{~mm})$ significantly influenced deep drainage that was significantly correlated with rainfall amount and intensity, but not with the duration of the dry interval. The result is consistent with the finding of $\mathrm{He}$ et al. (2012), who reported a lack of a significant correlation between the duration of the dry interval and the increase in soil 
water after rain events. This may be because rainfall intensity can only influence top soil layers $(0-40 \mathrm{~cm})$ but not deep soil layers (below $40 \mathrm{~cm}$ ), while the duration of dry intervals mainly caused soil surface evaporation in shallow soil layers. These results suggested that an event with large rainfall amount and intensity was more likely to increase the deep drainage, whereas the duration of dry interval cannot influence deep drainage in mobile sandy lands.

Mobile sandy lands play an important landscape-level role in the redistribution of rainwater (Berndtsson and Nodomi, 1996). Studies showed that the sand dunes covered with sparse natural vegetation have a strong water storage capability (Yin et al., 2011; Li et al., 2013; Yao et al., 2013). In our study, the average measured deep drainage ranged from 95.4 to $157.2 \mathrm{~mm}$, accounted for approximately $64.68 \% \pm 3.47 \%$ (mean $\pm \mathrm{SD})$ of the mean rainfall during the growing season. This result was higher than values reported in other studies. For example, Ma et al. (2013) indicated that modern direct recharge to the groundwater aquifers in the Dunhuang Basin is quite limited. The annual groundwater recharge in the Ordos Plateau of China ranges from $14 \%$ to $26 \%$ of the annual precipitation (Yin et al., 2011). Gates et al. (2008) reported that mean estimated diffuse recharge is only $1.4 \mathrm{~mm} / \mathrm{a}$, approximately $1.7 \%$ of the annual mean precipitation in the Badain Jaran Desert in northern China. However, the region in the Nebraska SandHills provided approximately $115 \pm 20 \mathrm{~mm} / \mathrm{a}$ of recharge to the aquifer (Billesbach and Arkebauer, 2012). Deep drainage from the bare sand in the Tengger Desert was $113.4 \mathrm{~mm} / \mathrm{a}$, which accounted for $40.5 \%$ of the annual precipitation (Wang et al., 2004; Li et al., 2013). This means that groundwater recharge has significant differences in the different regions, which depends on numerous local factors (Scanlon et al., 2006; Yeh et al., 2009; Huang et al., 2013; Jang et al., 2013). In our study, the high coefficient of deep drainage in mobile sandy lands may be partly attributed to strong infiltration capacity, low water holding capacity of sandy soil (mostly coarse and fine sands) (Table 1), low vegetation cover, rapid formation of a dry sand layer at the bare surface after rainfall, different precipitation patterns and soil types in the study sites (Alamusa et al., 2005; Sharda et al.,
2006; Zhao et al., 2007b; Gates et al., 2008; Risser et al., 2009; Huang and Pang, 2011). Moreover, it should be noted that deep drainage is the potential recharge rather than the actual groundwater recharge in mobile sandy lands. Thus, the relationship between precipitation and groundwater recharge should be further considered and studied in the future. Additionally, we observed large annual variability in rainfall amounts over the three years study (Fig. 6). Rainfall was significantly lower in 2010 than those in 2011 and 2012. However, coefficients of deep drainage were comparable among years. The number of total rainfall $>20$ mm exhibited significant differences among 2010, 2011 and 2012 (Table 2). Furthermore, the rainfall patterns were dominated by small rain events of $\leq 5$ $\mathrm{mm}$ in the study area, which accounted for $50 \%$ of the events in 2010, 2011 and 2012 (Table 2). Large rain events $(>20 \mathrm{~mm})$ were not sufficient to produce the present potential recharge rate of $64.68 \pm 3.47 \%$. Previous studies showed that the dry sand layer was a dominant and a limiting factor for soil water evaporation when its thickness was $>5 \mathrm{~cm}$ in a moving dune (Liu et al., 2006), and the soil depth of 40-60 cm was the lowest limit of soil water loss through evaporation in arid sandy lands (Feng and Cheng, 1999; He and Zhao, 2002). In unvegetated soil conditions, soil water was barely lost through evaporation at the soil depth greater than $100 \mathrm{~cm}$ (Zhao et al., 2007a). Our results also showed that soil water contents at the depth greater than $100 \mathrm{~cm}$ were relatively stable except for after large rain events during the study period (Fig. 4), indicating that the rainfall infiltrated to the depths below 40-60 $\mathrm{cm}$ or small rainfalls with limited infiltration depths were not fully consumed by evaporation from the soil surface, which were effective for replenishing soil water content to a certain extent. From our results, we could infer that although small rain events did not measurably affect soil water contents, continuous small rainfalls with short dry intervals can produce a superimposition effect which can increase initial soil water, and even form deep recharge. This inference is supported by He et al. (2012).

Based on the present results and previous researches, we concluded that rainfall infiltration in mobile sandy lands in this region can potentially increase soil water storage while recharging groundwater. Vegeta- 
tion was one of most successful methods to restore mobile sandy lands and to improve regional eco-environments in this region. However, after the reestablishment of vegetation in the desert, the soil water was used by plant growth and so no water percolation occurred (Wang et al., 2004). Consequently, unreasonable vegetation restoration in mobile sandy lands could even lead to reduction of potential recharge, and even the vegetation degradation in inter-dune lowlands and grassland in the region ( $\mathrm{Li}$ et al., 2013).

\section{Conclusions}

Small rain events might increase soil water content in the surface layers $(0-40 \mathrm{~cm})$, but not in the deep soil layers (below $40 \mathrm{~cm}$ ). Although small rain events cannot measurably affect soil water contents, continuous small rainfalls with short dry intervals could produce a superimposition effect which increased initial soil water, and even formed deep recharge. Large rain events $(>20 \mathrm{~mm})$ played an important role in increasing soil water content and producing deep drainage. A rain event with large rainfall amount and long duration resulted in deep infiltration. However, the soil water in deep soil layers would not be influenced by rainfall intensity and the duration of dry intervals. The average deep drainage rate in mobile sandy lands ranged from 95.4 to $157.2 \mathrm{~mm} / \mathrm{a}$, representing $61.30 \%-67.94 \%$ of precipitation of the growing season. Deep drainage of a single rain event was significantly correlated with rainfall amount and intensity, but not with the duration of the dry intervals. Our results suggest that the presence of mobile sandy lands in this region have a considerable potential to increase rainfall infiltration, thus improve soil water storage even to recharge groundwater.

\section{Acknowledgments}

This study was financially supported by the National Natural Science Foundation of China (41371053, 31270501), the National Science and Technology Planning Project (2011BAC07B02), and the Strategic Forerunner Project of Science and Technology, Chineses Academy of Sciences (XDA05050201-04-01), and the Special Scientific Research Fund (201109025-2). Authors thank all the members of the Naiman Desertification Research Station, Chinese Academy of
Sciences (CAS), for their help in field work. We also wish to thank anonymous reviewers for valuable comments on the manuscript.

\section{References}

Alamusa J D, Pei T F, Jiang D M. 2005. A study on soil moisture content and plantation fitness for artificial sand-fixation forest in Horqin Sandy Land. Advances in Water Science, 16(3): 426-431. (in Chinese)

Beatley J. 1974. Phenological events and their environmental triggers in Mojave desert ecosystems. Ecology, 55: 856-863.

Berndtsson R, Nodomi K. 1996. Soil water and temperature patterns in arid desert dune sand. Journal of Hydrology, 185: 221-240.

Billesbach D P, Arkebauer T J. 2012. First long-term, direct measurements of evapotranspiration and surface water balance in the Nebraska SandHills. Agricultural and Forest Meteorology, 156: 104-110.

Carpenter T M, Georgakakos K P, Sperfslagea J A. 2001. On the parametric and NEXRAD-radar sensitivities of a distributed hydrological model suitable for operational use. Journal of Hydrology, 253: 169-193.

Chenini I, Mammou A B, May M E. 2010. Groundwater recharge zone mapping using GIS-based multi-criteria analysis: a case study in Central Tunisia (Maknassy Basin). Water Resources Management, 24(5): 921-939.

Daly E, Porporato A. 2005. A review of soil moisture dynamics: from rainfall infiltration to ecosystem response. Environmental Engineering Sciences, 22(1): 9-24.

Delin G N, Healy R W, Lorenz D L, et al. 2007. Comparison of localto regional-scale estimates of ground-water recharge in Minnesota, USA. Journal of Hydrology, 334(1-2): 231-249.

Dunkerley D L, Booth T L. 1999. Plant canopy interception of rainfall and its significance in a banded landscape, arid western New South Wales, Australia. Water Resources Research, 35(5): 1581-1586.

Feng Q, Cheng G D. 1999. Moisture distribution and movement in sandy land of China. Acta Pedologica Sinica, 36(2): 225-236. (in Chinese)

Finch J W. 1998. Estimating direct groundwater recharge using a simple water balance model - sensitivity to land surface parameters. Journal of Hydrology, 211(1-4): 112-125.

Foley J L, Silburn D M. 2002. Hydraulic properties of rain impact surface seals on three clay soils-influence of raindrop impact frequency and rainfall intensity during steady state. Australian Soil Research, 40(7): 1069-1083.

Gates J B, Edmunds W M, Ma J Z, et al. 2008. Estimating groundwater recharge in a cold desert environment in northern China using chloride. Hydrogeology Journal, 16(5): 893-910.

He Z B, Zhao W Z. 2002. Variability of soil moisture of shifting Sandy land and its dependence on precipitation in semi-arid region. Journal of Desert Research, 22(4): 359-362. (in Chinese)

He Z B, Zhao W Z, Liu H, et al. 2012. The response of soil moisture to rainfall event size in subalpine grassland and meadows in a semi-arid mountain range: A case study in northwestern China's 
Qilian Mountains. Journal of Hydrology, 420-421: 183-190.

Heisler-White J L, Knapp A K, Kelly E F. 2008. Increasing precipitation event size increases aboveground net primary productivity in a semi-arid grassland. Oecologia, 158(1): 129-140.

Huang J, Wu P T, Zhao X N. 2013. Effects of rainfall intensity, underlying surface and slope gradient on soil infiltration under simulated rainfall experiments. Catena, 104: 93-102.

Huang T M, Pang Z H. 2011. Estimating groundwater recharge following land-use change using chloride mass balance of soil profiles: a case study at Guyuan and Xifeng in the Loess Plateau of China. Hydrogeology Journal, 19(1): 177-186.

Institute of Soil Sciences, Chinese Academy of Sciences (ISSCAS). 1978. Physical and Chemical Methods of Soil Analysis. Shanghai: Shanghai Science and Technology Press, 42-68. (in Chinese)

IUSS Working Group WRB. 2007. World Reference Base for Soil Resources 2006, first update 2007. World Soil Resources Reports No. 103. FAO, Rome.

Jang C S, Liou Y T, Liang C P. 2010. Probabilistically determining roles of groundwater use in aquacultural fishponds. Journal of Hydrology, 388(3-4): 491-500.

Jang C S, Chen S K, Kuo Y M. 2013. Applying indicator-based geostatistical approaches to determine potential zones of groundwater recharge based on borehole data. Catena, 101: 178-187.

Legates D R, Mahmood R, Levia D F, et al. 2011. Soil moisture: a central and unifying theme in physical geography. Progress in Physical Geography, 35(1): 65-86.

Li Y Q, Brandle J, Awada T, et al. 2013. Accumulation of carbon and nitrogen in the plant-soil system after afforestation of active sand dunes in China's Horqin Sandy Land. Agriculture, Ecosystems and Environment, 177: 75-84.

Liu H H. 2011. Impact of climate change on groundwater recharge in dry areas: An ecohydrology approach. Journal of Hydrology, 407(1-4): 175-183.

Liu W Z, Zhang X C, Dang T H, et al. 2010. Soil water dynamics and deep soil recharge in a record wet year in the southern Loess Plateau of China. Agricultural Water Management, 97(8): 1133-1138.

Liu X P, Zhang T H, Zhao H L, et al. 2006. Infiltration and redistribution process of rainfall in desert mobile sand dune. Journal of Hydraulic Engineering, 37(2): 166-171. (in Chinese)

Liu X P, He Y H, Zhao X Y, et al. 2011. Characteristics of precipitation in Naiman region of Horqin Sandy Land. Research of Soil and Water Conservation, 18(2): 155-158. (in Chinese)

Lucinda M, Richard T, Julian T, et al. 2008. Impact of rainfall distribution on the parameterization of a soil-moisture balance model of groundwater recharge in equatorial Africa. Journal of Hydrology, 359(1-2): 46-58.

Ma J Z, He J H, Qi S, et al. 2013. Groundwater recharge and evolution in the Dunhuang Basin, northwestern China. Applied Geochemistry, 28: 19-31.

Mehmet A. 2008. A model for evaporation and drainage investigations at ground of ordinary rainfed-areas. Ecological Modeling, 217(1-2): $148-156$.

Miller P C, Poole D K. 1983. The influence of annual precipitation, topography and vegetative cover on soil moisture and summer drought in southern California. Oecologia, 56(2-3): 385-391.

Morenode Las Heras M, Saco P M, Willgoose G R, et al. 2011. Assessing landscape structure and pattern fragmentation in semiarid ecosystems using patch-size distributions. Ecological Applications, 21(7): 2793-2805.

Naama R Y, Dan Y, Gabriel S, et al. 2012. Dynamics of evapotranspiration partitioning in a semi-arid forest as affected by temporal rainfall patterns. Agricultural and Forest Meteorology, 157: 77-85.

Pan Y X, Wang X P. 2009. Factors controlling the spatial variability of surface soil moisture within revegetated-stabilized desert ecosystems of the Tengger Desert, Northern China. Hydrological Processes, 23(11): 1591-1601.

Reynolds J F, Kemp P R, Ogle K, et al. 2004. Modifying the 'pulse-reserve' paradigm for deserts of North America: precipitation pulses, soil water and plant responses. Oecologia, 141(2): 194-210.

Risser D W, Gburek W J, Folmar G J. 2009. Comparison of recharge estimates at a small watershed in east-central Pennsylvania, USA. Hydrogeology Journal, 17(2): 287-298.

Rushton K R, Eilers V H M, Carter R C. 2006. Improved soil moisture balance methodology for recharge estimation. Journal of Hydrology, 318(1-4): 379-399.

Salve R, Sudderth E A, St. Clair S B, et al. 2011. Effect of grassland vegetation type on the responses of hydrological processes to seasonal precipitation patterns. Journal of Hydrology, 410(1-2): 51-61.

Scanlon B R, Keese K E, Flint A L, et al. 2006. Global synthesis of groundwater recharge in semiarid and arid regions. Hydrological Processes, 20(15): 3335-3370.

Schwinning S, Sala O E. 2004. Hierarchy of responses to resource pulses in arid and semi-arid ecosystems. Oecologia, 141(2): 211-220.

Sharda V N, Kurothe R S, Sena D R, et al. 2006. Estimation of groundwater recharge from water storage structures in a semi-arid climate of India. Journal of Hydrology, 329(1-2): 224-243.

Song D S, Zhao K, Guan Z. 2007. Advances in research on soil moisture by microwave remote sensing in China. Chinese Geographical Science, 17(2): 186-191.

Su Y Z, Zhao H L. 2003. Losses of soil organic carbon and nitrogen and their mechanisms in the desertification process of sandy Farmlands in Horqin Sandy Land. Scientia Agricultura Sinica, 36(8): 928-934. (in Chinese)

Su Y Z, Li Y L, Cui J Y, et al. 2005. Influences of continuous grazing and livestock exclusion on soil properties in a degraded sandy grassland, Inner Mongolia, northern China. Catena, 59(3): 267-278.

Timlin D, Pachepsky Y. 2002. Infiltration measurement using a vertical time-domain reflectometry probe and a reflection simulation model. Soil Science, 167(1): 1-8.

Tu X B, Kwong A K L, Dai F C, et al. 2009. Field monitoring of rainfall infiltration in a loess slope and analysis of failure mechanism of rainfall-induced landslides. Engineering Geology, 105(1-2): 134-150.

Tweed S, Leblanc M, Cartwright I, et al. 2011. Arid zone groundwater recharge and salinisation processes; an example from the Lake Eyre Basin, Australia. Journal of Hydrology, 408(3-4): 257-275. 
Wang S, Fu B J, Gao G Y, et al. 2013. Responses of soil moisture in different land cover types to rainfall events in a revegetation catchment area of the Loess Plateau, China. Catena, 101: 122-128.

Wang X P, Kang E S, Zhang J G, et al. 2004. Soil moisture dynamics in an artificially re-vegetated desert area. Advances in Water Science, 15(2): 216-222. (in Chinese)

Wang X P, Li X R, Xiao H L, et al. 2007. Effects of surface characteristics on infiltration patterns in an arid shrub desert. Hydrological Processes, 21(1): 72-79.

Wang X P, Cui Y, Pan Y X, et al. 2008. Effects of rainfall characteristics on infiltration and redistribution patterns in revegetation-stabilized desert ecosystems. Journal of Hydrology, 358(1-2): 134-143.

Wang X P, Wang Z N, Berndtsson R, et al. 2011. Desert shrub stemflow and its significance in soil moisture replenishment. Hydrology and Earth System Sciences, 15: 561-567.

Wythers K R, Lauenroth W K, Paruelo J M. 1999. Bare-soil evaporation under semiarid field conditions. Soil Science Society of America Journal, 63(5): 1341-1349.

Yamanaka T, Yonetani T. 1999. Dynamics of the evaporation zone in dry sandy soils. Journal of Hydrology, 217(1-2): 135-148.

Yao S X, Zhao C C, Zhang T H, et al. 2013. Response of the soil water content of mobile dunes to precipitation patterns in Inner Mongolia, northern China. Journal of Arid Environments, 97: 92-98.

Yaseef N R, Yakir D, Rotenberg E, et al. 2010. Ecohydrology of a semi-arid forest: partitioning among water balance components and its implications for predicted precipitation changes. Ecohydrology,
3: $143-154$.

Yeh H F, Lee C H, Hsu K C, et al. 2009. GIS for the assessment of the groundwater recharge potential zone. Environmental Geology, 58(1): 185-195.

Yin L H, Hu G C, Huang J T, et al. 2011. Groundwater-recharge estimation in the Ordos Plateau, China: comparison of methods. Hydrogeology Journal, 19(8): 1563-1575.

Zhang K B, Luo Y X. 1984. The investigation on the artificial regeneration of Haloxylon ammodendron and the approach of its rational density in Minqin region, Gansu Province. Journal of Beijing Forestry University, 6(1): 1-10. (in Chinese)

Zhang T H, Zhao H L, Li S G, et al. 2004. A comparison of different measures for stabilizing moving sand dunes in the Horqin Sandy Land of Inner Mongolia, China. Journal of Arid Environments, 58(2): 203-214.

Zhao H L, Zhou R L, Su Y Z, et al. 2007a. Shrub facilitation of desert land restoration in the Horqin Sandy Land of Inner Mongolia. Ecological engineering, 31(1): 1-8.

Zhao H L, Zhao X Y, Zhang T H, et al. 2007b. Bioprocess of Desertification and Restoration Mechanism of Degraded Vegetation. Beijing: Science Press, 188-210. (in Chinese)

Zhu Z D, Chen G T. 1994. Sandy Desertification in China. Beijing: Science Press, 61-62. (in Chinese)

Zuo X A, Zhao H L, Zhao X Y, et al. 2008. Spatial pattern and heterogeneity of soil properties in sand dunes under grazing and restoration in Horqin Sandy Land, northern China. Soil \& Tillage Research, 99(2): 202-212. 